\title{
Paying for Environmental Services
}

\author{
Raimundo C. G. Maciel1, Bastiaan P. Reydon², Jeísa A. da Costa1, \\ Gardênia de Oliveira Sales ${ }^{1}$ \\ ${ }^{1}$ Center for Applied Social and Juridical Sciences, Federal University of Acre, Rio Branco, Brazil \\ ${ }^{2}$ Institute of Economics, State University of Campinas, Campinas, Brazil \\ Email: rcgmaciel@bol.com.br
}

Received 14 January 2014; revised 16 February 2014; accepted 12 March 2014

Copyright (C) 2014 by authors and Scientific Research Publishing Inc.

This work is licensed under the Creative Commons Attribution International License (CC BY).

http://creativecommons.org/licenses/by/4.0/

(c) (i) Open Access

\begin{abstract}
The Amazonian economic occupation over the last forty years has been extremely harmful to the environment and to the traditional populations. One of the strategies to overcome this difficulty, dealing with sustainable development, is the development of productive units-starting with non-timber forest products (NTFP) - and the Payment for Environmental Services (PES) for the residents and/or owners of forest areas. The main problem which the literature demonstrates is that the estimated values paid for the PES are rather high, because they use the opportunity cost as reference, not considering the family reproduction social cost. The main aim of this study is to provide an alternative forecast of the value to be paid for the environmental services (PES) for the Amazon forest, based on the real costs of the forest communities maintenance, as based on the real economic needs of rural family production in the "Chico Mendes" Extractive Reserve (RESEX), in Xapuri (Acre state), Brazil. It was used a specific methodology, developed regionally, which measured and provided indicators to evaluate and to analyze the economic evolution of those families over the last decade. Based on the needs of family reproduction, the calculations require that the minimum value for PES should be US\$13 per hectare, a far lower and more appropriate value than the literature's average propositions that is around US\$50 per hectare. The present paper estimates that the costs of the PES in the Chico Mendes RESEX would be approximately US $\$ 5,767,000$ per year-taking into account the average area per family.
\end{abstract}

\section{Keywords}

Extractive Reserves (RESEX), Sustainable Development, Rural Family Production, Payment for Environmental Services (PES), Amazonian Region

\section{Introduction}

The rubber extraction in the Amazon forest has been an activity of great importance across the decades, since 
the beginning of the $20^{\text {th }}$ century. However, from the 1950s onwards, because of the growth in competition afforded by synthetic rubber and rubber produced through the system of plantation, mainly in Asia, obtaining rubber by the traditional extraction system in the forest has gone into a profound crisis.

In an attempt to check this trend, the Brazilian State implemented a variety of development strategies for the Amazon region. Such an example was “Amazonia Operation”, developed in 1966 with the aim of creating development zones and stable, self-sufficient population groups by stimulating migration, accompanied by incentives to private capital, improvements in the infrastructure and the identification of the natural resources potential.

With the crisis in the Amazonian rubber plantations, particularly in the second half of the $20^{\text {th }}$ century, many areas were sold to farmers from the southern states of Brazil, especially those from São Paulo, whose began to transform the forest into pasture land, destroying the means of survival of the extractivists. Many extrativists were expelled from the settlements ${ }^{1}$. Because of that, they found themselves obliged to migrate to the outskirts of towns, where they lived in precarious conditions without any prospects, mainly because they were a group of workers without any qualifications for typical urban employment. Their only experience was hard manual labor. Meanwhile, others remained in the rubber plantations, resisting the changes.

That was how the leader Chico Mendes arguing for the creation of Extractive Reserves (RESEX), a place where the extractivists would be assured the possession of land and the continuation of their traditional productive activities. According to Mendes, through the appropriate use of natural resources, the RESEX would be economically viable, enabling the exploitation of other forest products besides rubber (Hevea brasiliense) [1].

Moreover, the RESEX concept conforms to the Sustainable Development concept, since there is a constant search for alternatives to overcome the dichotomy between economic growth and environmental preservation. It is worth to note that sustainability comes from economic efficiency, social justice and ecological prudence, besides all, it also involves a harmonious relationship between man and his environment, thereby guaranteeing the benefits of the continued use of natural resources, both now and in the future [2]-[5].

Amongst the principal issues with which the RESEX proposal has dealt, can be listed the decentralization of land use, the encouragement of prudent use of natural resources and the conservation of biodiversity in the Amazon territory [6] [7].

In the words of Cavalcanti [4]:

Public policies dedicated to the development of Amazonia can no longer ignore the environmental challenge, expressed in the utilization of natural resources based on the principles of sustainability environmental challenge (...). Therefore, the creation of the Extractive Reserves assumes the relevance of the proposal as rubber tappers of Acre state, aiming towards the environmental conservation of the Amazon territory, defining a way of land using and land regulation (pg. 7).

Those who visualized the implementation and maturation of the RESEX as a suitable strategy for promoting social, economic and environmental development in Amazonia were side by side with those who considered it inadequate for this purpose. However,

The Extractive Reserves are not the panacea for Amazonia's ills, nor the magic solution for its occupation, once more than a half of the area has already been occupied and colonized by different projects, especially agricultural ones. Of the total surface area, maybe only $20 \%$ has the conditions required by law for their implementation. Precisely because they are coming on to the scene rather late, it is necessary to speed up the process in order to protect the areas that can still be protected [8].

In evaluating the economic efficiency of the iconic Amazonian product, i.e. rubber (Hevea brasiliense), Maciel and Reydon [9] explain that productive activity is technologically antiquated and presents a poor economic performance when it is compared to other activities. Its technological improvement under penalty of becoming unviable is extremely necessary, thereby confirming theories opposed to Amazonian development predicated on extractivism [10].

However, it is possible to modernize extractivist activities and make them sustainable. The Extractive Reserves are precisely important institutional innovations for the viability of productive alternatives in the heart of the forest, contributing therefore to the sustainable development of Amazonia, and particularly in the Acre State region [11].

Thus, the economic difficulties that the extractivist producers are facing today are closely related to the tech-

\footnotetext{
${ }^{1}$ Farming family production unit (FFPU) of the extractivist.

${ }^{2}$ Aviamento is a term coined in Amazonia, being a system of advancing merchandise on credit. The system involves the trader advancing goods and some working implements to the producer who repays the debt with extractive and agricultural products. Money is used purely as a reference, not as a medium of exchange.
} 
nological inheritance from the period of the so-called "aviamento" economy ${ }^{2}$. Certain bottlenecks to technological change are widely known, such as the difficulty of rationalizing production through prudent planting, but the economic history of the sector shows that these bottlenecks are related to constraints not only due to economic factors, but also due to result from politico-institutional and ecological factors (pg. 8) [9].

The aforementioned authors have stated that, in the quest for innovative solutions to overcome competitive disadvantages, the rubber tappers need interactive support from political, institutional and social factors, since, in order to innovate, it is necessary, as a first priority, to have access to the banks of scientific knowledge, which is becoming increasingly essential for technological progress.

Rêgo [12] states that, in order to make the sustainable development model for Amazonia work, it is necessary to have new public policies based on the very culture of the extractivist populations and on adequate systems of family production, by harmonizing the economic, social and environmental benefits, adapted to what he calls neo-extractivism.

In the view of Fearnside [13], the economy of the Brazilian Amazonia area would be almost entirely based on the destruction of the forest, through the predatory exploitation of timber or through deforestation for grazing cattle and, in some areas, for soybean. He goes on saying that the traditional sustainable activities such as rubber tapping (Hevea brasiliense) and Brazil nuts (Bertholetia excelsa) still exist, but their relative importance is minimal from the standpoint of cash flow in the current economy. Moreover, the financial return under which these uses can produce sustainable products is limited and frequently unfavorable in comparison with predatory uses, since the cost of environmental services is not incorporated into income streams derived from the traditional extraction plant.

Making the RESEX viable invariably means adopting strategies which coordinate actions aimed at the economic feasibility of productive activities as well as the positive interaction of these activities, while respecting the support capacity of the natural habitat which sustains it.

Therefore, the minimum economic conditions of the extractivists installed there should be identified, corresponding to a prudent use of resources. If, on the one hand, the extractivist is checked in the drive to advance, in a disorderly fashion, upon the existing resources because he has already satisfied his basic needs, made possible via the market, on the other hand, the prospect of benefitting from the existence of natural resources, both now and in the future, is protected.

As well, the present paper is proposing a feasible alternative for the payment of environmental services (PES) furthered by the extractivist communities more than a century ago. To this end, we are initially aiming to carry out a socio-economic evaluation of rural family production in the Chico Mendes RESEX, in Xapuri (Acre), with a view to offering a proposition that is consistent with the needs of the families which has being studied.

An extremely contemporary and provocative theme surrounding this debate about sustainable development in Amazonia relates to the PES, an instrument that remunerates or recompenses the producers who protect the forests. This is a way of encouraging conservation, ascribed to the sustainable exploitation of the forests, contributing decisively to the social reproduction of traditional populations, as well, of course, as the environment.

For Negret [14], when dealing with those families living under subsistence conditions in the RESEX, presenting serious difficulties for NTFP production and trading, the initiative of compensating environmental services - provided free of charge by the rural family producers, by virtue of the conservation and preservation of the forest—is justified in social and environmental terms, by improving in the quality of life.

It is patent that:

(...) the mechanisms of compensation and rewards for the conservation and restoration of environmental services can be important instruments for encouraging social, environmental and economic sustainability, especially for rural populations inhabiting strategic areas in the conservation of biodiversity, the production of water, the protection of springs and forests, the production of wholesome foods (...) [15].

According to Gusmão [15], the payment for environmental services is regarded as a powerful instrument in the attainment of sustainable development, applicable to the global domain, culminating in the inclusion of, and improvement in, the well-being of the forest producers.

In the domestic arena, certain mechanisms of compensation for environmental services do exist, such as the Chico Mendes Law (State Law no. 1.277/99) in force in the state of Acre, which pays the rubber producers a subsidy for the environmental services provided, to the tune of $\mathrm{R} \$ 0.70$ (seventy Brazilian cents) per kilo of rubber sold.

In the Brazilian state of Amazonas, a monthly benefit called the Forest Grant was introduced which was paid to families living in the State Conservation Units, as a means to encourage the producers to protect forest re- 
sources with the aim of reducing those practices considered predatory to the environment ${ }^{3}$.

In the international sphere, Costa Rica is a country that is conspicuous in its protection of the environment and natural resources, by adopting an innovative management mechanism whereby it provides remuneration of US\$64.00 per hectare protected [16].

Costa Rica recognizes the following environmental services: Reduction in emissions of pollutant gases; Protection of the water for urban, rural or hydroelectric use; Protection of biodiversity for conservation and sustained, scientific and pharmaceutical use, for the purposes of investigation and genetic enhancement; The protection of ecosystems and forms of life; Also its natural beauty for the purposes of tourism and science.

Moreover, there are a number of studies that seek to estimate appropriate values for the appraisal of environmental resources. By way of the example of Pearce and Pearce [17], which review an ample bibliography on the issue, by classifying forestry services into the categories of tropical forests and temperate forests, recommending values for the remuneration of diverse types of environmental services. For non-timber forest products, Pearce and Pearce [17] recommend compensation for services provided at US\$50.00 per hectare.

In this way, implementing a program of remuneration for the environmental services provided by those who safeguard the increasingly limited environmental factors essential to the equilibrium of the natural habitat, from the area of forest to air free from pollutant gases, is a valid strategy for guaranteeing everyone an "escape valve" from human intervention in the natural habitat, guaranteeing quality of life for human beings who are also part of this ecosystem.

\section{Methodology}

The object of the present study is the Chico Mendes Reserve, created in 1990, with an approximate area of 970,570 hectares, encompassing the municipalities of Assis Brasil, Brasiléia, Capixaba, Epitaciolândia, Rio Branco, Xapuri and Sena Madureira, in the Brazilian Acre State, and with a population of around 1500 families. The Farming Family Production Units (FFPU) being studied are known as settlements and consist, on average, of an area of 300 hectares. The manual labor resource is the family.

In order to perform a socio-economic evaluation of rural family production in the Chico Mendes RESEX, we worked with a suitable methodology specific to this type of production, which has been evolved over the last nine years by a research project called the Economic Analysis of Systems of Rural Family Production in the state of Acre. It is known locally as the ASPF, developed by the Department of Economics at the Federal University of Acre (UFAC) since $19966^{4}$. It should be emphasized that the present study is part of the aforementioned project.

Therefore, for the attainment of the study's objectives, we sought to work with a methodology based on socio-economic indicators and indices that, on the one hand, take into account the idiosyncrasies of the region under review. On the other hand, it serves as parameters to correlate the various regions and the specific forms of productive organization of the products traded, through internal comparisons and by the recommendation of working priorities for an effective and sustainable socio-economic development. There follows a succinct description of the research methodology.

The data survey, performed using sampling techniques, complied with the requirement that the producer must have resided in the settlement for at least two years.

The sample is determined based on three stages:

- Stratification of the area according to the level of development (high, medium or low), on the basis of criteria related to volume of production, ease and quality of access, availability of infrastructure and technical support, as well as the degree of community organization;

- A sampling of half of the groups in the areas under review_-branch ("ramal"), in the case of agricultural areas and "seringais"-rubber plantations in the case of the extractivist areas-keeping in mind the representativeness within each defined tier.

- Lastly, within each group selected, a simple random sample was taken by drawing $10 \%$ of the units of production, to comprise the object of the study.

For the information survey, the region's agricultural calendar was used as a point of reference, determined in conjunction with the communities under review, covering the period from May of the reference year to April the

\footnotetext{
${ }^{3}$ See http://fas-amazonas.org/programa-bolsa-floresta/.

${ }^{4}$ See http://aspf.wordpress.com/.
} 
following year, which comprises the group of productive, economic activities of the families. In the present evaluation, the agricultural years 1996/1997 and 2005/2006 were studied.

We worked with measurements of economic outcomes, namely indicators/indices which, given the costs of production, allow the measurement of economic performance for the system of production. Economic performance is the difference between the output and input values, the various relationships between output and input values and the fluctuations in the output values of the system of production.

The main economic indicators are briefly described below:

1) Gross Results

- Gross Income (GI) - indicator of the scale of production.

2) Net Results

- Net Income (NI)—appropriated surplus.

- Exploitation Profits- possibility of accumulation.

- Family Gross Margin (GM) - monetary amount available to the family.

- Quality of Life (QL) - monetary indicator of the standard of living.

3) Relationship Measurements

- Index of Economic Efficiency (IEE)—cost/benefit indicator.

- GM/Qm/d (Gross margin per volume of family labor per man day)-index of remuneration of family labor.

- Terms of Trade (TT) - index of appropriation of GI by the market.

4) Line of Market Dependency

- Rural family production partly depends on the market for the acquisition of products or goods and services necessary for its sustenance, especially biological ones, since a part of their consumption needs are satisfied by self-sufficiency and the rest is purchased in the marketplace.

- Thus, market dependency is defined as the median of values spent on market consumption, augmented by purchases related to the replacement of fixed capital (machinery, equipment, tools, property improvements etc.) available for maintaining the existing means of production.

5) Strategic evaluation [5] [18] [19].

- Here we worked with a number of indicators that seek to assess the availability and performance of assets, capacity building and competitive strategies.

\section{Results and Discussion}

\subsection{Socio-Economic Results of the Chico Mendes Extractivist Reserve}

Per Table 1 , it can be seen that, in nowadays, the extractives products, in relative terms, have lost a little of their importance as the main generator of gross income for the extractivist families in the Rubber Forest. Seeing that, in the 1996/1997 period, the extractivist products generated almost one-half of gross income for the families under review, with rubber and nuts standing out as the main products in the system.

However, in the 2005/2006 period, an abrupt fall in the yield of extractivist products can be seen, particularly the yield resulting from the production of rubber-accounting for just $9.57 \%$ of the revenues generated in the Chico Mendes RESEX, thereby demonstrating the production difficulties with this product. Nevertheless, extractivism continues to be the main activity in the Chico Mendes RESEX.

On the other hand, the drop in revenue from extractive products would have been worse if not for the earnings arising from the production and trading of Brazilian nuts, which has, in the last seven years, appreciated markedly in both the domestic and international markets. Added to this, there are the good practices introduced into the production process; certification and, consequently, new market niches with better prices, generating an alternative for the extractivist products.

In the 2005/2006 period, it can be seen that, in the product diversification process undertaken by the families on the Chico Mendes RESEX. Those products originating from livestock experienced an increase, with 30.37\% of the gross income of the productive system, with particular emphasis on cattle raising which, in nine years, has climbed from $13.34 \%$ to $17.59 \%$ of the income generated amongst the families on the Chico Mendes RESEX. From an environmental point of view, this is worrying since beef herd production is completely extensive and this obviously signifies that a greater expanse of pasture is required which leads to higher levels of deforestation-INSIDE THE RESEX! 
Table 1. Evolution of gross income in the Chico Mendes Resex, Acre, 1996/1997-2005/2006.

\begin{tabular}{ccc}
\hline Description & \multicolumn{2}{c}{$\%$ Gross Income } \\
\cline { 2 - 3 } Extractivism & $1996 / 1997$ & $\mathbf{4 5 . 3 4 \%}$ \\
Nuts & $\mathbf{4 8 . 0 4 \%}$ & $27.30 \%$ \\
Rubber & $25.18 \%$ & $9.57 \%$ \\
Certified Nuts & $22.86 \%$ & $3.69 \%$ \\
Agriculture & $0.00 \%$ & $\mathbf{2 4 . 2 8 \%}$ \\
Beans & $\mathbf{2 2 . 5 6 \%}$ & $1.79 \%$ \\
Rice & $5.09 \%$ & $7.37 \%$ \\
Cassava & $5.94 \%$ & $10.63 \%$ \\
Others & $6.06 \%$ & $4.50 \%$ \\
Livestock & $5.48 \%$ & $\mathbf{3 0 . 3 7 \%}$ \\
Poultry & $\mathbf{2 9 . 4 0 \%}$ & $5.24 \%$ \\
Beef & $6.55 \%$ & $17.59 \%$ \\
Pork & $13.34 \%$ & $6.07 \%$ \\
Others & $8.24 \%$ & $1.48 \%$ \\
\hline
\end{tabular}

Source: ASPF Database.

According to Table 2, the outcome of product diversification carried out by the extractivists in question indicates that the gross income of the families increased by over 6.92\% over the last nine years, there being a small increase in the monetary value (Family GM) pocketed by each family at the end of the period.

It can be seen that the NI obtained in the 96/97 agricultural year was well down while, in the most recent period, it has posted a period-on-period increase of $349.52 \%$. This is related to the type of production exploited in the settlements. Well, considering that the main product diversification consists of raising cattle and, to a lesser extent, pigs, it is obvious that the livestock is managed in the settlements in quite a rustic fashion, with a reduced quality of treatment of the livestock - in a phrase: pigs are raised like pigs and not like swine.

On the other hand, the increased income has led to the families in this location acquiring more goods in the market (Table 3) and, consequently, to reduce their self-sufficiency (Table 2). It can be observed that, over the last nine years, the region's standard of living has fallen. This shows that better incomes do not signify a better standard of living, in monetary terms.

It is worth pointing out that, when industrialized products replace self-sufficiency of products such as milk, poultry and other natural products, the quality of life, in health terms, declines. Moreover, with this substitution, a greater dependency on the market is apparent and, consequently, a greater need to generate revenues.

Table 3 validates this necessity. Seeing that, by virtue of having a greater disposable monetary value (GM) for the family, thereby making it possible to purchase more goods and services, the fixed costs of the unit of production increased, with the replacement and acquisition of more items of fixed capital, such as machinery, equipment, beasts of burden, property improvements etc.

One factor, which led to this change, was the visible improvement in physical access to the locations, providing the producers with easier transportation to the city markets. However, this generated a debt greater than there had been previously. By increasing income, more was purchased due to the repressed demand for the necessary merchandise for reproduction of the family and the FFPU, however, these purchases went beyond the increase achieved over the last nine years.

The difficulties created by the economic inefficiency of the farming family production units can be glimpsed from Chart 1, seeing that 90\% of families living inside the Chico Mendes RESEX receive a level of remuneration from the productive process which is lower than their consumption needs essentially supplied by the market.

It is worth to note that around $70 \%$ of families do not manage to provide half of the aforementioned necessities, thereby evidencing the difficulties with the generation and appropriation of income inside the RESEX, principally deriving from the non-timber forest products. This requires them to search for alternative strategies to make up their income, especially from the productive point of view-notably along the path of the depreda- 
Table 2. Evolution of economic performance in the Chico Mendes Resex, Acre, 1996/1997-2005/2006.

\begin{tabular}{ccccc}
\hline Indicators & Unit & $1996 / 1997$ & $2005 / 2006$ & Variance \\
\hline Gross Income & $\mathrm{R} \$ /$ month & 318.00 & 340.00 & $6.92 \%$ \\
Net Income & $\mathrm{R} \$ /$ month & 33.70 & 151.49 & $349.52 \%$ \\
Gross Family Margin & $\mathrm{R} \$ /$ month & 267.26 & 291.39 & $9.03 \%$ \\
Self-sufficiency & $\mathrm{R} \$ /$ month & 310.81 & 268.36 & $-13.66 \%$ \\
Quality of Life & $\mathrm{R} \$ /$ month & 619.19 & 583.56 & $-5.75 \%$ \\
Index of $\quad$ Economic Efficiency & & 0.92 & 0.59 & $-36.29 \%$ \\
Terms of Business & & 0.69 & 1.03 & $49.91 \%$ \\
\hline
\end{tabular}

Source: ASPF Database.

Table 3. Economic performance results on the Chico Mendes Resex, Acre, 2005/2006.

\begin{tabular}{ccc}
\hline Indicators & Unit & Results by FFPU* (2005/2006) \\
\hline Gross Income (GI) & $\mathrm{R} \$$ month & 340.00 \\
Total Gross Income (TGI) & $\mathrm{R} \$ /$ month & 439.17 \\
GI \% of TGI & $\%$ & $77 \%$ \\
Quality of Life & $\mathrm{R} \$ /$ month & 583.56 \\
Dependent on Salaried Employment & $\%$ & $25 \%$ \\
Dependent on Handouts & $\%$ & $43 \%$ \\
\hline
\end{tabular}

Source: ASPF database.

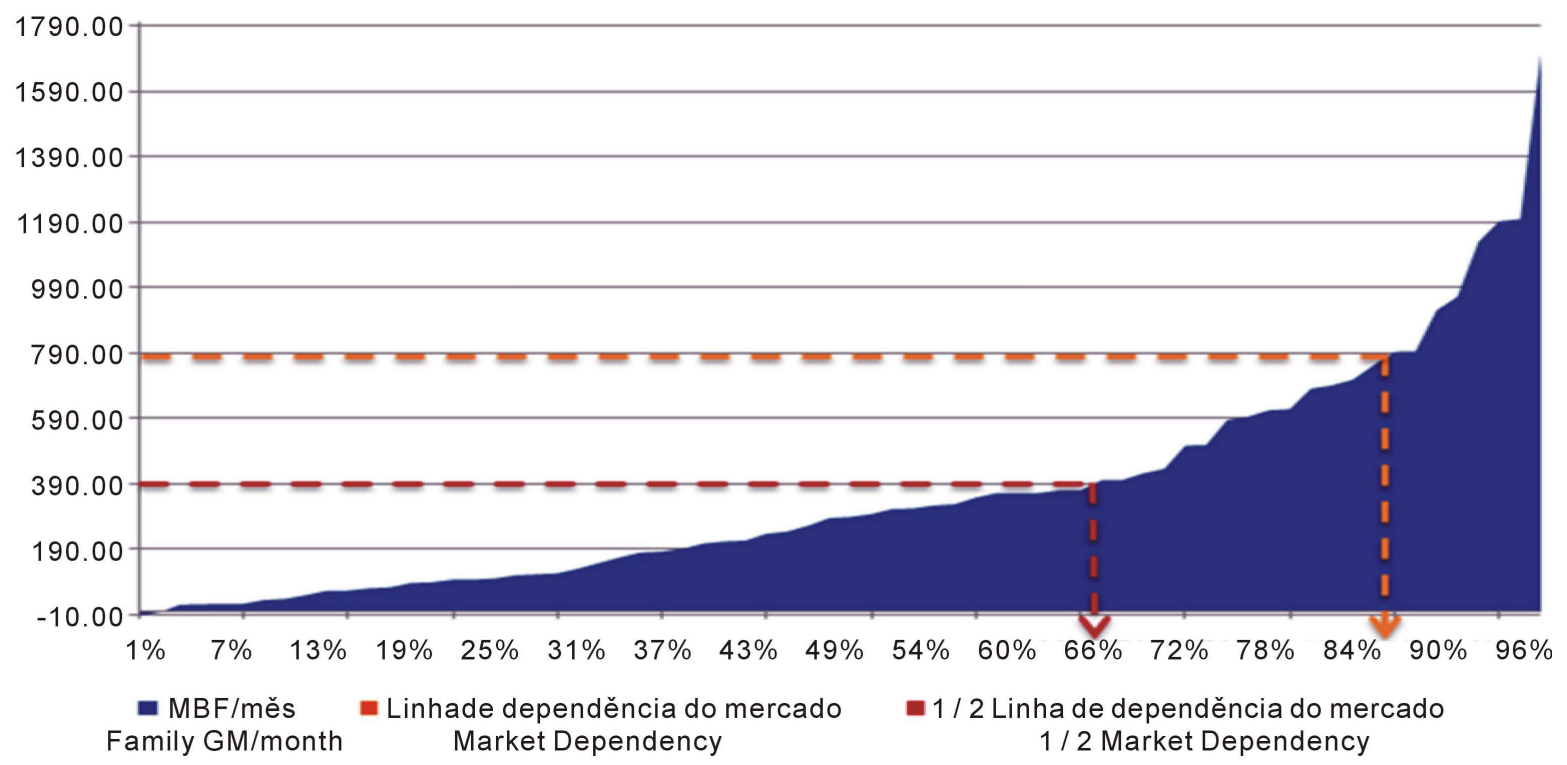

Chart 1. Line of market dependency of the Chico Mendes Resex, 2005/2006, Acre.

tory alternatives, as is the case with cattle raising and timber production.

Moreover, to cover their debts, the families took salaried employment outside the FFPU, as well as receiving government income payments. That is to say, according to Table 3, one third of the families studied have family members working outside the FFPU and who receive remuneration that contributes to the family income. Moreover, $43 \%$ of the settlements studied have at least one family member receiving some or other benefit, such as a pension or grants offered by the federal government. This shows that many families have a certain degree of dependency on salaried employment and handouts, which emerged precisely to help with the sustenance of low-income families, though not with the aim of creating dependency.

Nevertheless, it should be stressed that even with the difficulties of sustenance in the forest region, it is not worthwhile for the extractivists to abandon their settlements and move to the outskirts of the cities. According to 
Table 2, the total quality of life (QL), in monetary terms, represents around 1.4 monthly minimum salaries, which is a significant income when compared with the earnings of populations considered poor, who live in these city outskirts.

Furthermore, it can be seen that the difficulties encountered by the extractivists lie precisely in the low earnings mainly from the production and trading of non-timber forest products, particularly because of the low prices of products with established markets, exemplified by rubber and nuts.

However, these markets are failing in not paying adequately for these products by virtue of the socio- environmental benefits that these offer. The most interesting feature to observe in Chart 2 is that the producers themselves allege that the attributes, which make them more competitive, derive from their socio-environmental attributes (localization, or in other words, living in the forest itself and the reputation for product quality) of the non-timber forest products produced inside the RESEX.

It may be said, therefore, that the extractivist families could be on a higher level in terms of quality of life, including the environmental conditions in which they are living, if they were appropriately remunerated for the historical environmental protection, which they have been exercising for more than a century, producing riches that are effectively appropriated by others.

In this sense, the payment to extractivists for environmental services, particularly in the RESEX reserves, becomes crucial given the derailments of the development process witnessed in Amazonia, since the ecosystemic services, as well as the traditional populations, which have always maintained them, are under serious threat.

\section{Towards a Proposal for Payment for Environmental Services-PPES}

Given the results presented in the previous topic, a payment for environmental services provided by the rural working families is proposed as an incentive to practicing the sustainable use of resources extracted in the heart of the forest. In this way, both social reproduction and the sustenance of the forest ecosystem can be made viable, by rewarding those "responsible for the management of the forest" for the services provided to society in general.

As a last resort, the proposals for payments for environmental services at an international level determine the amount of remuneration based on opportunity cost, as is evident in the region under review. Although, the present study proposes a different perspective, to the detriment of opportunity cost, where the maintenance of environmental services is observed based on the social cost required for family reproduction, that is to say, on the minimum required to make the families and their modus vivendi viable.

Hence, the creation is proposed of a Program for the Payment of Environmental Services (PPES) whose purpose is to preserve natural resources based on the preservation of the minimum sustenance and reproduction conditions of the extractivist family production units.

On the one hand, the proposed payment is conditional on the line of family reproduction that represents the minimum remuneration required for the family to cover the costs of goods and services purchased in the mar-

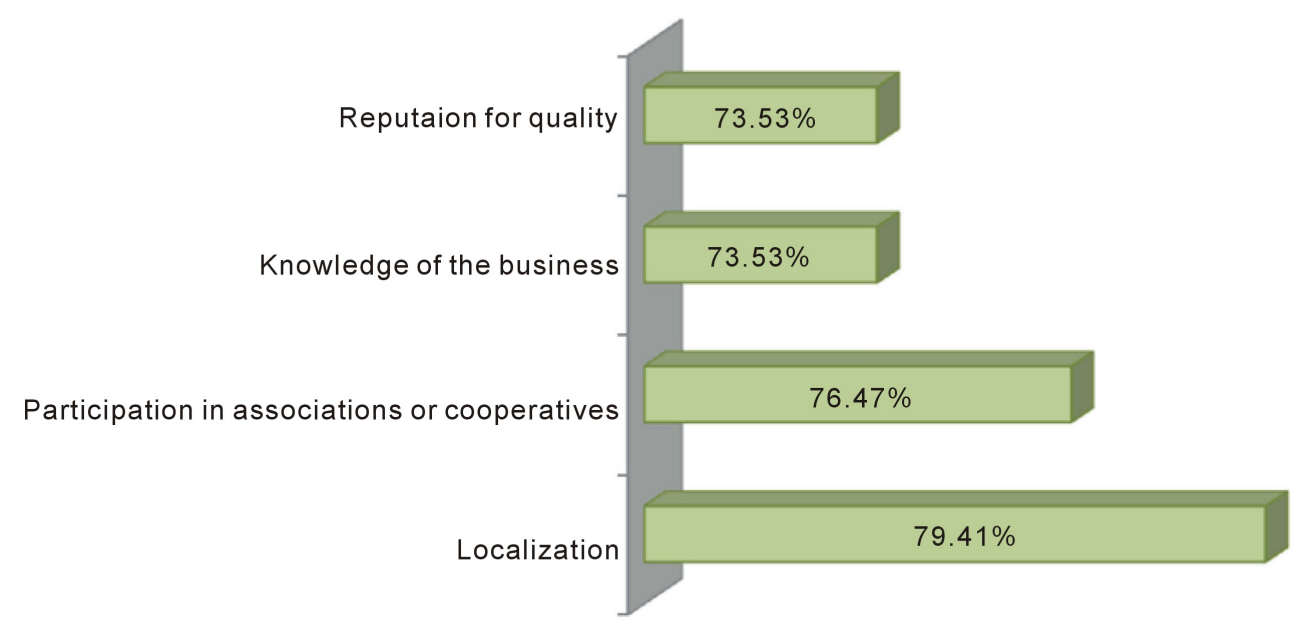

Chart 2. Strategic assessment: availability of assets and capacity building (advantage) on the Chico Mendes Resex, Acre, 2005/2006. 
ketplace, as well as the replacement of fixed costs to maintain the productive unit in normal operation. On the other hand, it is also conditional on the gross revenues earned from the trading of predetermined NTFPs, relating to the management and the adequate volume of production for the maintenance of the environment.

This mechanism works as a trigger since, while the families do not manage to attain the income necessary to cover such necessities through their own productive efforts, the program for the payment for environmental services works by covering the difference needed for family reproduction.

The beneficiaries of this program will be the extractivist families who earn their livelihood by exploiting the NTFPs in the Chico Mendes Extractivist Reserve.

For the Chico Mendes RESEX region, the line of family reproduction, in monetary terms, was calculated at a median value of around R\$9376.00 per annum, per FFPU.

However, as shown in Table 4, taking into account purely the income arising from the NTFPs—by virtue of the fact that the other productive activities carried on in the FFPUs are clearly subsistence or self-sufficiencythe families would receive on average $\mathrm{R} \$ 2840.00$ per annum, from the trading of the two main NTFPs: rubber and nuts.

Therefore, the difference to be made up by the Program for the Payment of Environmental Services would be $\mathrm{R} \$ 6536.00$ per annum per FFPU. It is calculated that $\mathrm{R} \$ 9,804,000.00$ per annum is required to cover PES costs for the whole of the Chico Mendes RESEX.

The budget forecast for the PES would be established according to the performance of the unit of production as a whole. However, the actual payment for the services provided would be pegged to the trading of the products that are representative of the NTFPs.

For this proposal, the products of rubber and nuts have been specified since, in addition to being representative products, they involve activities that have been carried on for more than one hundred years, which, in their traditional forms and limitations, respect the environment's capacity to support them.

Accordingly, taking into consideration the historical averages for rubber production, if all the PES were paid to this product, the extractivist, as well as earning income from normal trading, would also receive around $\mathrm{R} \$ 10.89$ per kilogram traded. Alternatively, if he were paid only based on the trading of Brazilian nuts, the producer's income would rise by $\mathrm{R} \$ 32.68$ per can (Table 4).

The fact is that the producer would receive a credit of $\mathrm{R} \$ 6536$ per annum, which can be deducted from the remuneration of the combination of the aforementioned NTFPs or specifically from one product. Hence, it may be amply promoted in terms of the adaptation to other regions producing different NTFPs and/or products complementary to rubber and nuts, it being sufficient merely to recalculate the PES to be remunerated per unit traded of a particular, representative product. Moreover, the PES can be reduced via an increase in NTFP productivity, bringing about an increase in the income generated and, consequently, a reduction in PES remuneration to equip the farming family production unit with minimum maintenance conditions.

Another implicit factor is the notion of production limits, bearing in mind that, having established the maximum PES value and remuneration per unit of product, the issue of volume of production is also discussed. This effectively satisfies the proposal in terms of the socio-environmental aspect.

From the point of view of production, it is the case that environmental services will be remunerated, at most, for the historical average of NTFP production, amounting, in the case of rubber, to $600 \mathrm{~kg}$ per annum per FFPU. In this way, the environmental limits are respected, discouraging the extractivist from producing beyond this point, thus having a positive impact on the process of species regeneration.

On the other hand, from the financial standpoint, due to the existence of a scenario that favors financial compensation for services provided, it should be stressed that the establishment of a fixed value presupposes the

Table 4. Proposed values for the PES in the Chico Mendes RESEX, Acre, Brazil-values in R\$.

\begin{tabular}{ccccccccc}
\hline NTFP & Qty & Unit & Price & GI & LFR & $\begin{array}{c}\text { PES } \\
\text { Per Product }\end{array}$ & $\begin{array}{c}\text { PES } \\
\text { Total per FFPU }\end{array}$ & $\begin{array}{c}\text { PES } \\
\text { Chico Mendes RESEX }\end{array}$ \\
\hline FFPU & - & - & - & $2,840.00$ & & & & $9,804,000.00$ \\
Rubber & 600.00 & $\mathrm{~kg}$ & $1.40^{*}$ & 840.00 & $9,376.00$ & 10.89 & 6536.00 & \\
Nuts & 200.00 & Can & 10.00 & 2000.00 & & 32.68 & & \\
\hline
\end{tabular}

N.B. ${ }^{*}$ Without the subsidy enacted by the Chico Mendes Law, since the current proposal might replace it; ${ }^{* *}$ Price to be paid for one single product taking into account the PES; NTFP—Non-timber Forest Products; Qty.—Quantity; GI—Gross Income; LFR—Line of Family Reproduction; PES—Payment for Environmental Services; FFPU—Farming Family Production Unit; RESEX—Extractivist Reserve. 
impossibility of opportunist behavior. Therefore, as payment for the environmental services, it is proposed to have a minimum value required to satisfy family reproduction in the region under review. In other words, it is primarily sought to preserve the conditions that are sufficient to maintain the individual who safeguards the environment and, simultaneously, the conservation of natural/environmental resources would be supported. In this way, both man and his environment are protected.

In this context, livestock farming, and particularly beef stocks, as well as the farming of items such as rice, beans, corn and cassava, habitually unsustainable from an economic and environmental point of view, given the level of technology employed by the families, will be satisfactorily stimulated for self-sufficiency production and, in the case of the beef herds, a store of value.

The PES proposal was developed to bring up-to-date the Chico Mendes Law, existing in the Brazilian state of Acre, which remunerated the environmental services performed by the extractivists based on their rubber production. Based on this upgrade of the Chico Mendes Law, unified in the PES, a suitable instrument is secured for remunerating environmental services, having as a point of reference any non-timber forest product.

PES remuneration is rooted in the production of non-timber forest products, being associated on the one hand with an activity which has historically shown itself to be environmentally sustainable and, on the other hand, having a specific remuneration limit per product, thereby discouraging the extractivists from exceeding the limits of historical production for a specific product. In this way, the PES methodology espoused here follows the proposition of sustainable development, also by considering the traditions and habits of the forest communities and the boundaries of the environment under consideration.

As an alternative to funding such a proposal, the work of Gusmão [15] may be quoted, which lists a series of legal provisions that will guarantee protection for natural resources based on financial compensation for whomsoever protects them or uses them in moderation.

One example of these mechanisms is Law 8.510/90, of the state of São Paulo, which establishes that $25 \%$ of the ICMS (merchandise circulation tax, or VAT equivalent) collected, should be distributed amongst the municipalities which promote the preservation of the environment. In addition, he quotes the Chico Mendes Law that originally offered a subsidy of $\mathrm{R} \$ 0.60$ per $\mathrm{kg}$ of rubber, having been readjusted upwards in 2005 to a value of $\mathrm{R} \$ 0.70 / \mathrm{kg}$.

In the Brazilian state of Amazonas, the government launched the Forest Grant, a mechanism that remunerates families who do not depredate the region. Each family receives a monthly sum corresponding to $\mathrm{R} \$ 50.00$ in return for forest conservation.

Addition to all this, there also exist other potential fundraising mechanisms in the program that may represent the safeguarding of the forest area under review. For example, the National Forest Development Fund (NFDF) instituted by Law 11.284/2006, the Public Forest Management Law that establishes a levy for the use of forest resources with the aim of making the maintenance of these forests a viable proposition.

\section{Conclusions}

In Amazon Region, productive alternatives are sought for the promotion of the much-publicized sustainable development, or in other words, economically efficient, socially just and environmentally sound alternatives, especially for the traditional communities in the region, clearly excluded from the forms of economic occupation implemented after the 1970s.

The Extractivist Reserves have emerged as an alternative for sustainable development. However, throughout the process of implementation, the families living in these areas are finding it immensely difficult to maintain themselves and this has led them to diversify their production towards predatory activities, such as the raising of beef herds, which represents a serious problem in terms of the deforestation arising from this activity.

In this paper, we observe the low earnings generated by the NTFPs, which are being replaced by income from cattle farming. Nevertheless, livestock besides not guarantee the maintenance of families, is providing increasing deforestation in the heart of the forest.

As an income alternative, a payment is proposed for the environmental services provided by the extractivists living on the RESEX, particularly the Chico Mendes reserve, giving a glimmer of hope for the conservation of both the families and the forest environment.

After all, the proposal aims to guarantee conditions that are sufficient for the reproduction of the families and the productive unit itself, shifting the focus from environmental appreciation, notably in respect of opportunity 
cost, to the coverage of the social cost, which ultimately also deals with environmental conservation.

Therefore, it should be emphasized that the values resulting from the proposal are seen as capable of being implemented bearing in mind that the PES arising was around US\$13 (or R\$22.00) per hectare, well below the average sum proposed by literature and also below that currently in practice in Costa Rica, of around US\$50 per hectare.

\section{References}

[1] Batista, A.V.C. (1995) Reservas Extrativistas: Origem, Defesa e Questionamento. Rio Branco, AC: 1995.

[2] Sachs, I. (1986) Ecodesenvolvimento: crescer sem destruir. Vértice, São Paulo.

[3] CMMAD (1991) Nosso Futuro Comum. 2nd Edition, Editora da Fundação Getúlio Vargas, Rio de Janeiro, 430 Pages.

[4] CAVAlCANTI (2002) Francisco Carlos da S. A Política Ambiental na Amazônia: Um Estudo sobre as Reservas Extrativistas. Campinas: IE/UNICAMP, 240 Pages. (Thesis presented to the Institute of Economics at UNICAMP as a partial requirement for obtaining the title of Doctor of Economics).

[5] MACIEL, Raimundo C. G. (2007) Certificação Ambiental: uma estratégia para a conservação da floresta amazônica. Campinas: [s.n.], 175 p. (Thesis presented to the Institute of Economics at UNICAMP as a partial requirement for obtaining the title of Doctor of Applied Economics).

[6] ALLEGRETTI, Mary Helena. (1989) Reservas Extrativistas: Uma proposta de desenvolvimento da floresta amazônica. Revista Pará Desenvolvimento, Extrativismo Vegetal e Reservas Extrativistas, Belém, n. 25, 3-29.

[7] (1995) COSTA FILHO, Orlando Sabino da. Reserva Extrativista—Desenvolvimento Sustentável e Qualidade de Vida. 1995. 156 Pages. Dissertation (Masters in Economics)—Federal University of Minas Gerais, Belo Horizonte.

[8] UICN (1995) Reservas Extrativistas. UICN, Cambridge, 133 Pages.

[9] Maciel, R.C.G. and Reydon, B.P. (2003) Ilhas de Alta Produtividade: inovação no ambiente amazônico. Congresso Brasileiro de Economia e Sociologia Rural, XLI., 2003, Juiz de Fora. Anais... Juiz de Fora: SOBER, 2003. 18 pages (1 CD-ROM).

[10] Homma, A.K.O. (1993) Extrativismo vegetal na Amazônia: Limites e oportunidades. EMBRAPA-SPI, Brasília, 202 pages.

[11] Maciel, R.C.G. (2003) Ilhas de Alta Produtividade: Inovação essencial para a manutenção dos seringueiros nas Reservas Extrativistas. Campinas: IE/UNICAMP, 2003. 88 pgs. (Masters Dissertation-Economic Development, Space and Environment, IE/UNICAMP).

[12] Rêgo, J.F. (1999) Amazônia: do extrativismo ao neoextrativismo. Ciência Hoje, 25. 62-65.

[13] Fearnside, P.M. (2008) Amazon Forest maintenance as a source of environmental services. Anais da Academia Brasileira de Ciências, 80. http://biodiversidadeacreana.blogspot.com/2008/03/amazon-forest-maintenance-as-source-of.html

[14] Negret, F. (2008) Brasil—Compensação dos Serviços Ambientais aos Agricultores Familiares. http://www.adital.com.br/site/noticia.asp?lang=PT\&cod=28063

[15] Gusmao (2008) Andressa Veronique Pinto. Problemas ambientais globais e a compensação por serviços ambientais como alternativa para a proteção do capital social e ecológico. http://jus2.uol.com.br/doutrina/texto.asp?id=6341

[16] Fonafifo (2008) Fondo Nacional de Financiamento Forestal. http://www.fonafifo.com/paginas_espanol/servicios_ambientales/servicios_ambientales.htm

[17] Pearce, D.W. and Pearce, C.G.T. (2001) The Value of Forest Ecosystems. Convention on Biological Diversity.

[18] Aaker, D.A. (1989) Managing Assets and Skills: the key to a sustainable competitive advantage. California Management Review, 31, 91-106. http://www.periodicos.capes.gov.br

[19] Chandler, G.N. and Hanks, S.H. (1994) Market Attractiveness, Resource-Based Capabilities, Venture Strategies, and Venture Performance. Journal of Business Venturing, 9, 331-349. http://www.periodicos.capes.gov.br http://dx.doi.org/10.1016/0883-9026(94)90011-6 